Brazilian Journal

of Chemical

ISSN 0104-6632

Printed in Brazil

Engineering

www.scielo.br/bjce

Vol. 35, No. 03, pp. 847-856, July - September, 2018

dx.doi.org/10.1590/0104-6632.20180353s20170175

\title{
APPLICABILITY OF WOOL COVALENT BONDED Bacillus circulans 25 CELLS FOR MILK-CLOTTING ENZYME PRODUCTION BY BATCH, REPEATED BATCH AND CONTINUOUS PROCESS
}

\author{
Samia A.Ahmed ${ }^{1 *}$, Mohamed A. Abdel-Naby ${ }^{1}$ and Ahmed F. Abdel-Fattah ${ }^{1}$ \\ ${ }^{1}$ Chemistry of Natural and Microbial Products Department, National Research \\ Centre, Dokki, Cairo, Egypt
}

(Submitted: April 10, 2017; Revised: June 19, 2017; Accepted: August 22, 2017)

\begin{abstract}
The production of milk-clotting enzyme (MCE) by free and immobilized Bacillus circulans 25 cells was investigated. The investigation evaluates cell immobilization through entrapment and covalent binding to different carriers. B. circulans 25 cells immobilized covalently via glutaraldehyde (cross-linker) to natural wool exhibited higher effectiveness factor (0.76) compared to other carriers. Immobilized cells produce maximum level of MCE and highest ratio of milk-clotting activity/proteolytic activity (MCA/PA) after $24 \mathrm{~h}$ using $0.4 \mathrm{~g}$ wet weight cells/g wool. In batch operation, decreasing biomass loading to $0.2 \mathrm{~g}$ enhanced the MCA/PA ratio and specific productivity by 5.94 and $59.88 \%$, respectively. Immobilized cells on natural wool as an effective and suitable carrier were able to produce the same level of MCA, productivity and MCA/PA ratio for 9 repeated cycles $(216 \mathrm{~h})$. Under continuous operation immobilized cells in a packed-bed bioreactor were able to keep producing MCA with MCA/PA ratio for about 7 days at the same level. Moreover, continuous operation demonstrates a very good productivity of $0.385 \mathrm{KU} / \mathrm{L} / \mathrm{h}$, which is higher than the other production systems by $7.0-11.7$ fold. Immobilized $B$. circulans 25 cells proved to be fully capable of continuous MCE production in a packed-bed bioreactor.
\end{abstract}

Keywords: Milk-clotting enzyme; Batch; Repeated batch; Continuous production; Packed-bed bioreactor.

\section{INTRODUCTION}

Traditionally used as a milk coagulant, calf rennet plays a critical role in the cheese production. However, decreasing number of slaughtered calves has led to an increased price of calf rennet versus the increasing demand of coagulant in the production of cheese necessitates the exploration for potential substitutes (Hang et al., 2016; Lemes et al., 2016). Candidate calf rennet substitutes has mainly been resourced from animals (Shamtsyan et al., 2014), plants (Shah et al., 2014), genetic engineering and microorganisms
(Lemes et al., 2016) but their applications may be limited by factors such as cultivation and climatic variations, which can affect theirproduction and supply. Thus, microbial enzymes (Microlant) are attractive and potential alternatives for milk coagulation (Lemes et al., 2016) due to their stability, availability, rapid growth, cheaper cost, greater biochemical diversity, easier genetic modification and offer a variety of properties and religious or dietary reasons (Ahmed et al., 2016; Hang et al., 2016; Lemes et al., 2016). Most proteolytic enzymes coagulate milk, but in most cases no stable cheese is formed, as the coagulum is

*Corresponding author. E-mail address: dr_sa_ahmed@yahoo.com 
further digested by continued proteolysis. Good MCE is characterized by a high specific caseinolytic activity and a low general proteolytic activity. Moreover, the proteolysis strongly affects the textural and sensory properties of cheese (Shah et al., 2014). Biocatalyst immobilization is one of the techniques based on the fixation of the biocatalyst into or onto various carriers, which can improve whole cell applications (Krasňan et al., 2016). Using immobilized cells for biochemical processes offers several advantages over the conventional free cell systems including increased robustness of the biocatalyst, higher cell density, higher productivity, possibility of cell recovery and reuse, lower downstream costs associated with cell separation, improved cell resistance to toxic and inhibitory compounds, better process, storage stability and facilitating continuous operation (Niknezhad et al., 2016; Siddiqui et al., 2016). Application of immobilization biocatalysts generally includes the production of chemicals, pharmaceuticals and food products (Saieb et al., 2015). Over the years, many immobilization techniques have been developed and the basic methods are adsorption, covalent binding, cross-linking, encapsulation, and entrapment. An industrial carrier for food fermentations should be cheap, nontoxic, stable to microbial degradation, with low diffusional limitation, reusable, high surface area, and appropriate density for the reactor type (Eş et al., 2015). Natural wool possesses rich reactive residues (such as lysine, serine, and glutamic acid), which might be used in surface activation in the immobilization process. Furthermore, its rigid structure and wide availability makes wool an attractive candidate as an immobilization carrier. The surface of untreated wool is quite hydrophobic, cell immobilization onto this surface can then be achieved by using glutaraldehyde (GA) as a cross-linking agent due to its fast reaction and low toxicity. The most widely accepted theory on the GA cross-linking mechanism is that the aldehyde groups in GA react with the lysine residues in the protein through a Schiff base reaction (An et al., 2014). Repeated batch fermentation is considered useful technology for enhancing the productivity due to the reduction in fermentation time and removal of the inoculum preparation step (Reddy et al., 2016). A packed- bed reactor is the most commonly used immobilized cell reactor in industry (Eş et al., 2015). The bioreactor consisted of a packed- bed of immobilized cells and its operation involved recycling of the broth through the bed (Sirisansaneeyakul et al., 2007). The present study focused on the production of MCE by the immobilized cells on different carriers.
The productivity of MCE was evaluated using the immobilized cells of $B$. circulans 25 in batch, repeated batch, and continuous cultures in packed- bed bioreactors.

\section{MATERIALS AND METHODS}

\section{Microorganism}

Bacillus circulans 25 was obtained from the Culture Collection of the National Research Centre, Dokki, Cairo, Egypt and was maintained on nutrient agar (Merck Co.) slants at $35^{\circ} \mathrm{C}$ and transferred weekly.

\section{Carriers for cell immobilization}

Agar and sodium alginate were obtained from BDH Chemical Ltd., Poole, England.

Charcoal was from ADWIC Company, Egypt. Acrylamide, $\mathrm{N}, \mathrm{N}$-methylene bis-acrylamide and $k$ -carragenan were obtained from Sigma Chemical Co., USA. Chicken bone, ceramic, glass wool and natural wool were collected from the local market in Egypt.

\section{Culture media and growth conditions}

The basal medium used for enzyme production had the following composition $(\mathrm{g} / \mathrm{L})$ : lactose 20.0 , yeast extract 1.0, peptone 1.0, $\mathrm{K}_{2} \mathrm{HPO}_{4} 2.0, \mathrm{MgSO}_{4} \cdot 7 \mathrm{H}_{2} \mathrm{O}$ 0.25 . The $\mathrm{pH}$ was adjusted to 6.0 prior to sterilization. One $\mathrm{mL}$ of cell suspension of $24 \mathrm{~h}$-old slant $\left(\mathrm{OD}_{600} \sim 0.3\right)$, was transferred to $250-\mathrm{mL}$ Erlenmeyer flask each containing $50 \mathrm{~mL}$ production medium. The flasks were incubated at $35^{\circ} \mathrm{C}$ on a rotary shaker at 180 rpm for $24 \mathrm{~h}$.

\section{Determination of the biomass}

The optical density (OD) of the cell growth was measured at $600 \mathrm{~nm}$ using a spectrophotometer (Spectronic 2000, Busch \& Lomb). The wet weight of cells was measured by centrifugation of a certain volume of the cultivated medium $(6000 \mathrm{x} g, 15 \mathrm{~min}$ at $4^{\circ} \mathrm{C}$. The cell pellets were washed with $0.09 \mathrm{M} \mathrm{NaCl}$, collected by centrifugation and weighed. The cell dry weight was determined after heating the cell pellets at $50^{\circ} \mathrm{C}$ to a constant weight.

\section{Cell immobilization procedures}

All the immobilization processes were performed under aseptic conditions. The viable cells of $B$. circulans 25 obtained in the logarithmic phase of growth were collected by centrifugation $(6000 \mathrm{x} g, 15$ 
$\min$ at $4^{\circ} \mathrm{C}$. Then, the wet cells were suspended in 0.85 $\%$ sterile $\mathrm{NaCl}$ and used for cell immobilization. The same amount of the free cells was inoculated along with the immobilized cells, under identical conditions.

\section{Immobilization by entrapment}

\section{In Ca-alginate}

The viable cells of $B$. circulans 25 obtained from $50 \mathrm{ml}$ culture ( $0.4 \mathrm{~g}$ wet weight cells) were mixed with $10 \mathrm{~mL} \mathrm{Na}$-alginate solution $(3.0 \% \mathrm{w} / \mathrm{v})$. The mixture was then added dropwise to $3 \%$ sterile solution of $\mathrm{CaCl}_{2}$ with continuous gentle stirring. The produced gel beads were further hardened by allowing them to stand in $3 \% \mathrm{CaCl}_{2}$ solution at room temperature for $2 \mathrm{~h}$. The beads $(\sim 2.0 \mathrm{~mm})$ were then recovered by screening and washed with sterile distilled $\mathrm{H}_{2} \mathrm{O}$. The obtained beads were used for inoculation of $50 \mathrm{~mL}$ of the production medium (Sirisansaneeyakul et al., 2007).

\section{In agar and k-carrageenan}

The same amount of the viable cells obtained from $50 \mathrm{ml}$ culture $(0.4 \mathrm{~g})$ were mixed with $10 \mathrm{~mL}$ of $3 \%$ $(\mathrm{w} / \mathrm{v})$ agar or $k$-carrageenan solution at $45^{\circ} \mathrm{C}$ and was quickly cooled to $4^{\circ} \mathrm{C}$, cut into $2 \times 2 \times 2 \mathrm{~mm}$ fragments, and transferred to $50 \mathrm{~mL}$ of the production medium (Cheetham et al., 1985).

\section{In polyacrylamide}

The viable cells obtained from $50 \mathrm{~mL}$ culture $(0.4$ g) were mixed with $10 \mathrm{~mL}$ of $5 \%(\mathrm{w} / \mathrm{v})$ acrylamide solution with $3 \%(\mathrm{w} / \mathrm{w})$ cross-linker (N,N-methylene bisacrylamide). The gel obtained was cut into fragments $(2 \times 2 \times 2 \mathrm{~mm})$ and was used for inoculation of $50 \mathrm{~mL}$ of the production medium (Chibata et al., 1976).

\section{Immobilization by covalent binding}

In separate experiments, $1 \mathrm{~g}$ of each carrier (charcoal, ceramic, glass wool, chicken bone, and natural wool) was treated with $10 \mathrm{~mL}$ of $0.025 \%$ GA for $24 \mathrm{~h}$. The carriers were collected by centrifugation $(6000 \mathrm{x} g, 15$ min at $4^{\circ} \mathrm{C}$ and washed with sterile distilled $\mathrm{H}_{2} \mathrm{O}$ to remove the excess GA. Then the viable cells obtained from $50 \mathrm{~mL}$ culture $(0.4 \mathrm{~g})$ were incubated with $1 \mathrm{~g}$ of each treated carrier in $10 \mathrm{~mL}$ of saline. The carriers were collected by centrifugation, washed with sterile distilled $\mathrm{H}_{2} \mathrm{O}$ and were used for inoculation of $50 \mathrm{~mL}$ of the production medium (Abdel-Naby et al., 2011).

\section{Optimization of the immobilization process}

\section{Effect of glutaraldehyde concentration}

The effect of GA concentration was tested by treating the natural wool with different concentrations of GA ranging from 0.025 to $0.3 \%$. In all cases, the viable cells obtained from $50 \mathrm{~mL}$ culture $(0.4 \mathrm{~g}$ wet cells) were immobilized on $1 \mathrm{~g}$ of wool treated with GA

\section{Effect of biomass loading}

In separate experiments, $1 \mathrm{~g}$ of $0.25 \%$ GA treated wool was mixed with different wet cell concentrations (0.2- $0.8 \mathrm{~g})$.

\section{Production of milk-clotting enzyme}

\section{By free cells in batch experiment}

Unless otherwise stated, the batch experiments of free cells were performed in 250- mL Erlenmeyer flasks, each containing $50 \mathrm{~mL}$ production medium. The flasks were inoculated with $1 \mathrm{~mL}$ cell suspension $\left(\mathrm{OD}_{600} \sim 0.3\right)$ and incubated at $35^{\circ} \mathrm{C}$ and $180 \mathrm{rpm}$ for 24 h. The cultivated culture medium was centrifuged at $4^{\circ} \mathrm{C}, 6000 \times \mathrm{g}$, for $15 \mathrm{~min}$ and the clear culture filtrate was taken for enzyme assay.

\section{By immobilized cells}

\section{In batch experiment}

The batch experiments of the immobilized cells were performed in $250-\mathrm{mL}$ Erlenmeyer flasks, each containing $50 \mathrm{~mL}$ of sterile medium. The flasks were inoculated with the beads resulting from $1 \mathrm{~g}$ natural wool. The flasks were incubated at $35^{\circ} \mathrm{C}$ and $180 \mathrm{rpm}$ for $24 \mathrm{~h}$. The cultivated medium was centrifuged at $6000 \mathrm{x} g, 4^{\circ} \mathrm{C}$ for $15 \mathrm{~min}$ and the supernatant was taken for enzyme assay.

\section{In repeated batch experiment}

This was done in 250-mL Erlenmeyer flasks, each containing $50 \mathrm{ml}$ sterile medium. Each flask was inoculated with the calculated amount of immobilized cells on $1 \mathrm{~g}$ natural wool (containing $0.2 \mathrm{~g}$ wet cells). Fermentation was conducted at $35^{\circ} \mathrm{C}, 180 \mathrm{rpm}$ for 24 $h$. At the end of each run, the beads before transferring 
to the fresh medium were washed with tris- $\mathrm{HCl}$ buffer (0.01 M, pH 6.0) and distilled $\mathrm{H}_{2} \mathrm{O}$ under sterile conditions.

\section{In continuous fermentation using bioreactor}

The packed- bed reactor is a glass column 1.8 $\mathrm{cm}$ in diameter and $32.0 \mathrm{~cm}$ in long (Figure 1). The reactor was filled with $173 \mathrm{~g}$ of freshly prepared immobilized beads comprising $5.25 \mathrm{~g}$ of wet weight of viable cells. The bioreactor volume was $325 \mathrm{~mL}$. The bed volume was $93 \mathrm{~mL}$, whereas the working volume (void volume) was about $232 \mathrm{~mL}$. The fresh medium was introduced from the bottom of the bioreactor. Air was admitted in through a sterile air filter from the bottom of the bioreactor. The fermentation was conducted at $35^{\circ} \mathrm{C}$ and carried out in batch operation for $24 \mathrm{~h}$, then the continuous operation was started at different dilution rates $(0.05-0.7 / \mathrm{h})$. The air flow was adjusted at $0.3 \mathrm{v} / \mathrm{v} / \mathrm{min}$. The system was considered to be in a steady state only after at least 5 residences times (replacement volumes) and the effluent from the reactor was collected in a holding tank.

\section{Enzymes assays}

\section{Milk-clotting activity (MCA)}

MCA was determined by the method reported by Berridge (1952). Enzyme solution $(2.5 \mathrm{~mL})$ was incubated with $10 \mathrm{~mL}$ of reconstituted skim milk from the Ministry of Agriculture, Giza. Egypt (12\% in 0.01 $\mathrm{M} \mathrm{CaCl}_{2}$ ) at $40^{\circ} \mathrm{C}$ and the clotting time was recorded. One unit of the enzyme activity (U) was equalized to $10 \mathrm{~mL}$ milk, clotted within $10 \mathrm{~min}$.

\section{Proteolytic activity (PA)}

PA was determined according to the casein digestion method described by Deane et al. (1986). The reaction mixture contained $1.0 \mathrm{~mL}$ of enzyme preparation and $1.0 \mathrm{~mL}$ of $1.5 \%$ casein solution in tris- $\mathrm{HCl}$ buffer $(0.01$ $\mathrm{M}, \mathrm{pH}$ 6.0). The reaction mixture was incubated for $30 \mathrm{~min}$ at $40^{\circ} \mathrm{C}$. Then $2.0 \mathrm{~mL}$ of trichloroacetic acid (15\%) were added and the mixture was centrifuged at $6000 \mathrm{x} g$ for $10 \mathrm{~min}$. The solubilized proteins in the supernatant were measured using the method of Lowry et al. (1951). One unit of the enzyme activity (U) is defined as the amount of the enzyme that releases one $\mu$ mole of tyrosine $/ \mathrm{mL}$.

\section{Protein determination}

The protein content was determined by the method of Lowry et al. (1951).

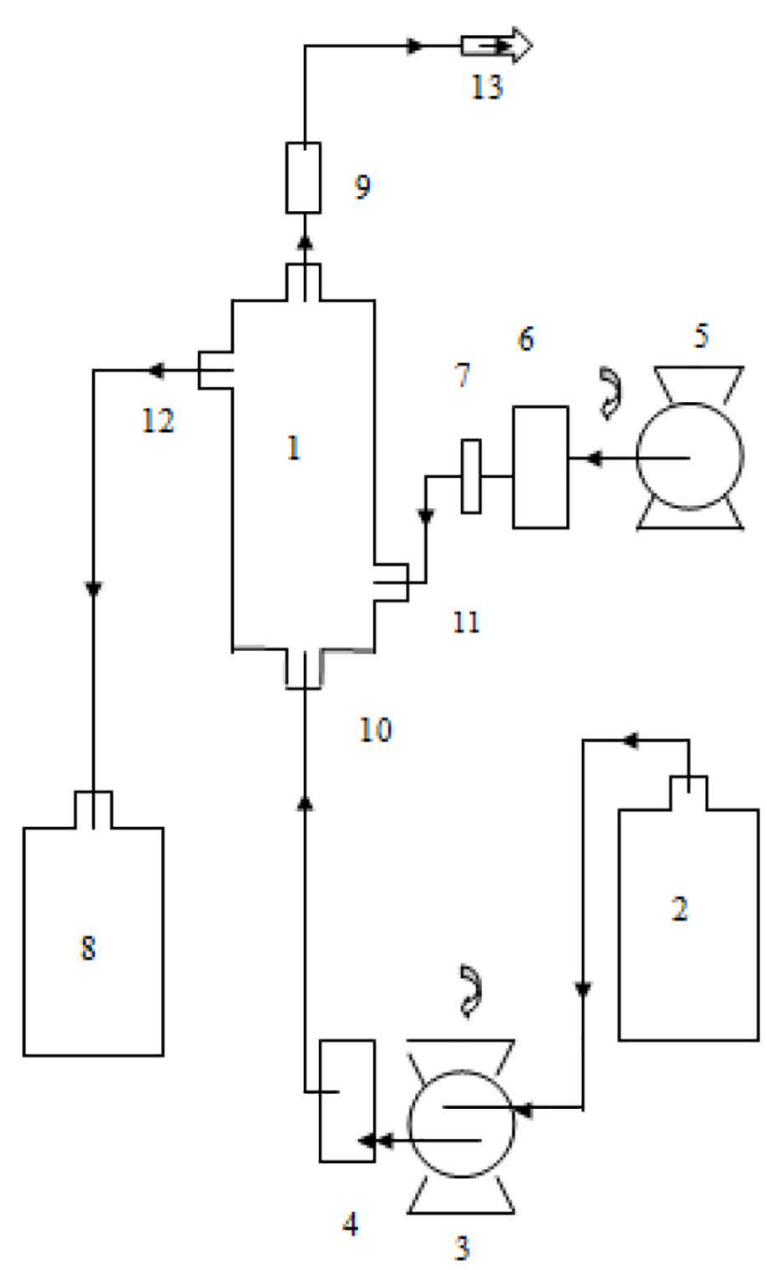

Figure 1. Schematic diagram of the continuous fermentation system. (1) The column bioreactor, (2) medium feed reservoir, (3) peristaltic pump, (4) flow rate regulator, (5) air pump, (6) rotameter, (7) air filter, (8) product collection vessel, (9) outlet air filter (10) medium inlet, (11) air inlet, (12) product outlet, (13) air outlet.

\section{RESULTS AND DISCUSSION}

\section{Fermentation course for the production of MCE by $B$. circulans $\mathbf{2 5}$ free cells}

The results illustrated in Figure 2 showed that maximal MCA $(1.33 \mathrm{U} / \mathrm{mL})$ with maximal ratio of MCA/PA (15.1) was reached after $24 \mathrm{~h}$, increasing the time to $48 \mathrm{~h}$ decreased the MCA by $80 \%$. This result is superior to that obtained by Wu et al. (2013), who produced crude enzyme from $B$. subtilis natto with a MCA/PA ratio of 6.4 . On the other hand, maximal $\mathrm{PA}(0.14 \mathrm{U} / \mathrm{mL})$ was reached after $48 \mathrm{~h}$ and remained stable up to $60 \mathrm{~h}$ incubation period. The ratio of MCA/ $\mathrm{PA}$ is an important factor for the enzyme for industrial use in cheese production and it should be considered to obtain stable curd with good quality. The viable cells 


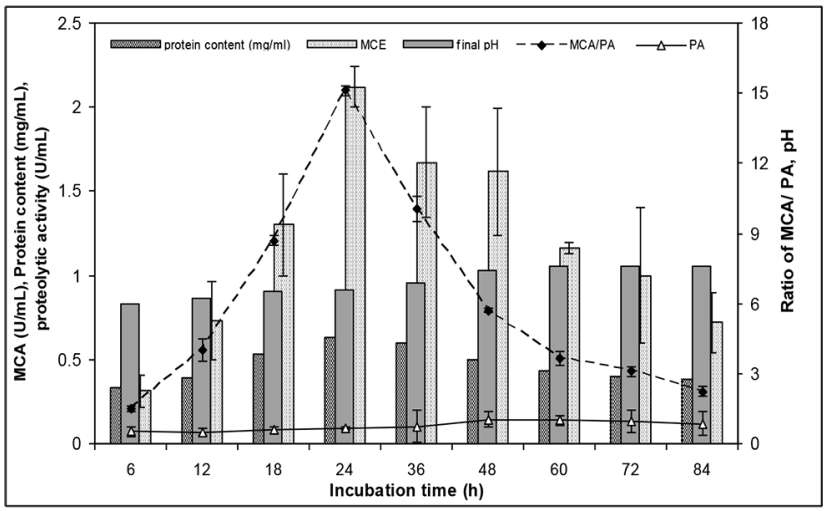

Figure 2. Fermentation course for the production of MCE by free B. circulans 25 cells.

obtained in the logarithmic phase of growth (24 h) were used for the immobilization process.

\section{Production of MCE by immobilized B. circulans 25 cells}

The efficiency of the immobilization process is evaluated by different parameters including MCA, the effectiveness factor of the immobilization $(\mathrm{EF}=\mathrm{MCA}$ of the immobilized cells/ MCA of the same amount of free cells under identical conditions), and the rate of product synthesis. The specific productivity (U/g wet cells/h) is the key parameter. Due to the special application of MCE, the ratio of MCA/PA of the enzyme produced by immobilized cells should be considered. In all cases of our study, the MCA obtained from the immobilized cells was lower than that obtained from the same amount of free cells, and the EF of the immobilized cells was lower than one. This is because the immobilized cells represent a heterogeneous catalysis fermentation, in which the synthesis of primary or secondary metabolites is dependent upon the external and internal mass transported (Abdel-Naby et al., 2011).

\section{Immobilized cells by entrapment}

As shown in Figure 3A, B. circulans 25 cells were entrapped in different gel carriers (agar, Ca-alginate, $\kappa$-carrageenan and polyacrylamide). B. circulans 25 cells entrapped in $\kappa$-carrageenan gel showed the highest ratio of MCA/PA (4.6), highest specific productivity (4.17 U/g wet cells/ h) and highest EF (0.613). This result is in line with that reported by Konti et al. (2016), who entrapped Pseudomonas putida DSM 437 cells in Ca-alginate with $\mathrm{EF}<1$ (0.73). On contrary, Saieb et al. (2015) found that alginate immobilized B.licheniformis cells recorded higher enzyme production than free cells.
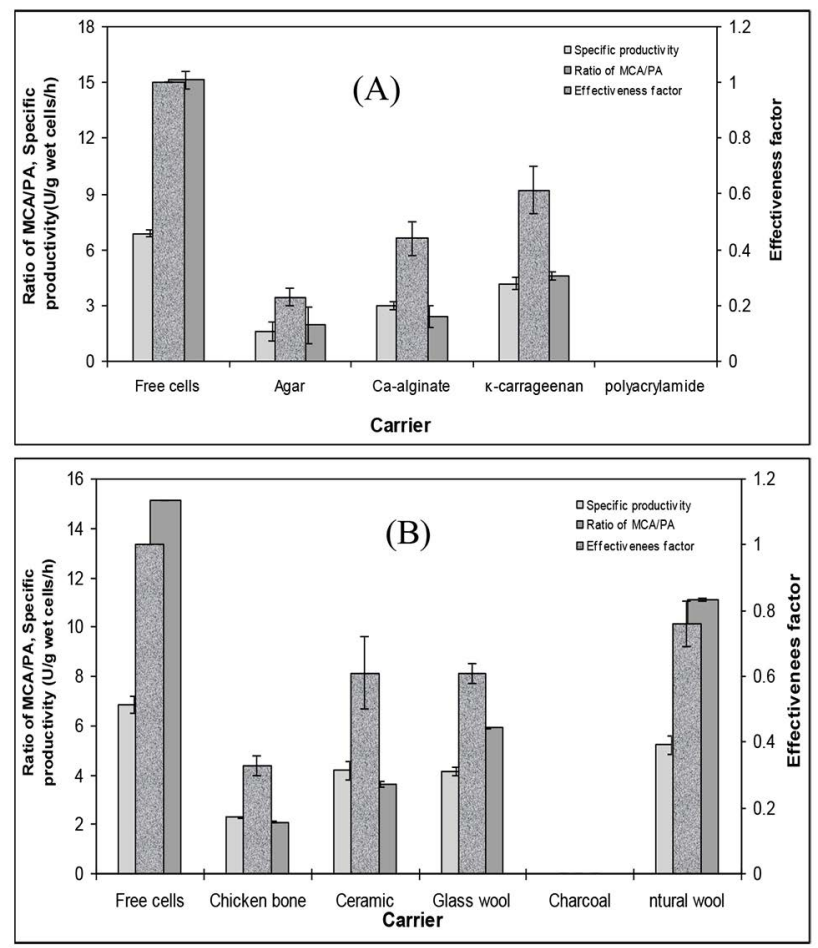

Figure 3. Immobilization of $B$. circulans 25 cells (A) by entrapment, (B) by covalent binding.

\section{Immobilized cells by covalent binding}

B. circulans 25 cells were covalently bounded to different treated carriers with GA (chicken bone, ceramic, glass wool, charcoal and natural wool) for MCE production and were compared with the same amount of the free cells. Data illustrated in Figure 3B showed that $B$. circulans 25 cells were successfully immobilized on natural wool with highest ratio of MCA/PA (11.11), highest specific productivity (5.21 $\mathrm{U} / \mathrm{g}$ wet cells/ h) and highest EF (0.76). Protocols for covalent biocatalyst immobilization using GA as spacer group often begin with a surface modification or activation step showing good loading efficiency and prevent the cells from leaking out. This good loading efficiency might be due to the formation of stable cross linking between functional groups present on the surface of the carrier and functional groups belonging to amino acid residues on the surface of the biocatalyst. In addition, covalent binding through a spacer group probably increased the local surface area of the carrier and consequently the biocatalyst molecule (Chang et al., 2008; AbdEl-Ghaffar and Hashem, 2010). The suitable carrier must have mechanical resistance against the conditions of applications, zero toxicity, size-flexible matrix, allowing internal cell growth for different microorganisms, and it must be non-biodegradable (Krasňan et al., 2016). Unlike 
the materials for cells immobilization described in previous publications, natural wool not only has more compact structure and is easily manipulated, but also more reliable in the fabrication of various reactor geometries for continuous use. The immobilized $B$. circulans 25 cells on natural wool are highly recommended for dairy production.

\section{Optimization of immobilization process}

\section{Effect of glutaraldehyde concentration}

The results (Figure 4a) showed that the highest MCA/PA ratio (11.11) with highest specific productivity $(5.21 \mathrm{U} / \mathrm{g}$ wet cells/h) was obtained from treated wool with $0.025 \%$ GA. Higher concentrations of GA led to a gradual decrease in MCA and MCA/PA ratio. On the other hand, the immobilized $B$. circulans 25 cells on treated wool with $0.3 \%$ GA showed no MCA. Bagherinejadet al. (2012) reported that the optimum GA concentration for immobilization of $E$. coli cells was $5 \%$.
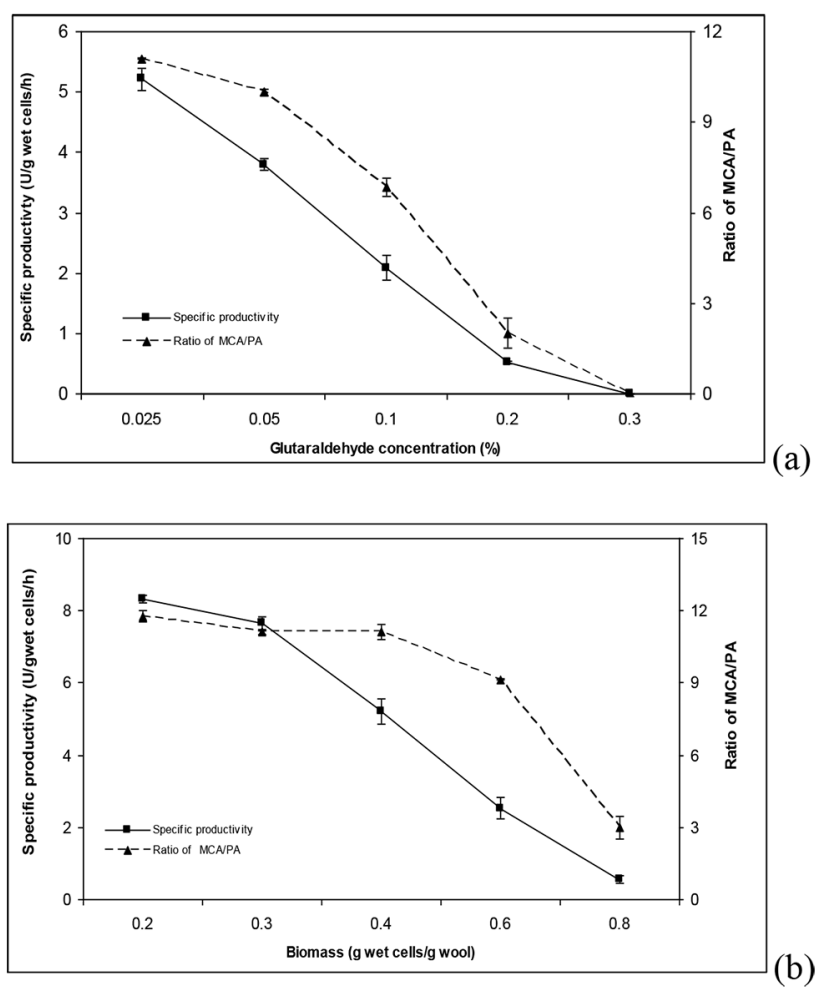

Figure 4. Effect of (a) glutaraldehyde concentration, (b) biomass loading on immobilization of $B$. circulans 25 cells on natural wool.

\section{Effect of biomass loading}

The apparent specific productivity of the immobilized cells depends on the amount of the biomass loaded on the immobilization carrier. As shown in Figure $4 \mathrm{~b}$ the highest specific productivity $(8.33 \mathrm{U} / \mathrm{g}$ wet cells/h) and highest MCA/PA ratio (11.77) were obtained with a cell load of $0.2 \mathrm{~g}$ wet cells/g wool. Gradual increase of the cell load up to $0.4 \mathrm{~g}$ decreased the specific productivity to about 62.5 $\%$ compared with that obtained at a cell loading of 0.2 g. The higher cell concentrations did not show any further improvement in enzyme production, which might be attributed to substrate limitations or product inhibition (Panesar et al., 2007).

\section{Production of MCE by immobilized cells under optimum conditions}

\section{In batch}

From the above experiments it can be concluded that immobilized $B$. circulans 25 cells on natural wool produced the highest ratio of MCA/PA (11.77) with the highest specific productivity $(8.33 \mathrm{U} / \mathrm{g}$ wet cells/h) using $0.2 \mathrm{~g}$ wet cells/ $\mathrm{g}$ wool treated with $0.025 \% \mathrm{GA}$ after $24 \mathrm{~h}$ incubation at $35^{\circ} \mathrm{C}$ and $180 \mathrm{rpm}$.

\section{In repeated batch}

In batch culture, both fermentation time and the production cycle led to a reduction in overall productivity and add to the production costs. Therefore, the possibility of reuse of immobilized cells was investigated. The optimized conditions for the immobilization and the optimized fermentation medium were used. Repeated batch fermentations (Figure 5) demonstrated the feasibility of using immobilized cells for multiple fermentation cycles. The $B$. circulans 25 cells immobilized on natural wool were reused to produce MCE successfully for 9 cycles $(216 \mathrm{~h})$ with productivity $(1.5-1.66 \mathrm{U} / \mathrm{h}), \mathrm{MCA}(0.71$ $0.80 \mathrm{U} / \mathrm{mL}$ ) and the $\mathrm{MCA} / \mathrm{PA}$ ratio remaining between 11.72 and 12.49 . The loss in activity after that might be due to destruction of cells as well as autolysis during the centrifugation and washing process. The stability of the immobilized B. circuulans 25 cells is lower than that obtained by Ahmed and Abdel-Fattah (2010) in the production of protease by immobilized B. licheniformis ATCC 21415 cells on wool (480 h). Our result is higher than that obtained by Costa et al. (2015), who found that the productivity of immobilized B. circulans DF 9R cells was considered only for 6 cycles.

\section{In continuous production}

Continuous production of MCE by the immobilized cells of $B$. circulans 25 was accomplished in a 


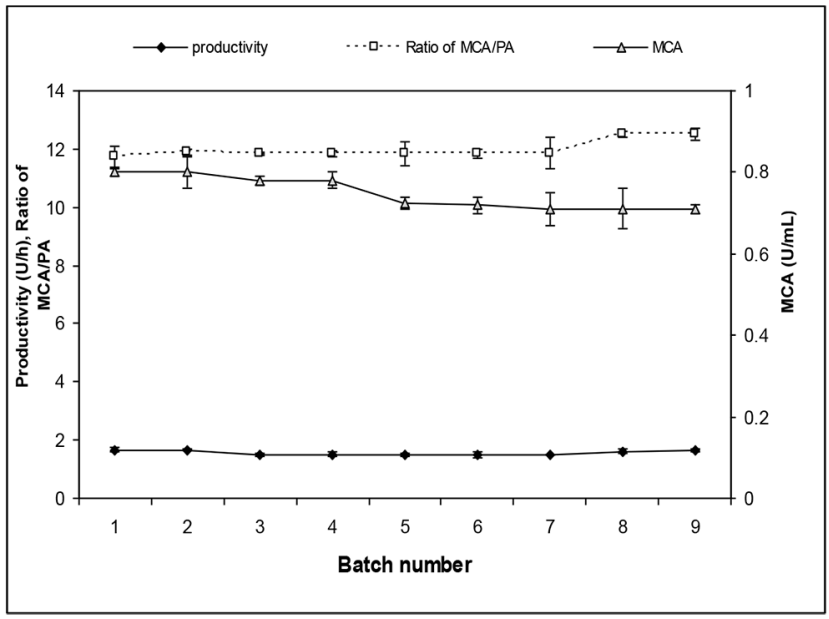

Figure 5. Production of MCE by immobilized cells in repeated batch operation.

packed-bed reactor. The fermentation was carried out in batch operation for $24 \mathrm{~h}$, and then continuous operation was started. The flow rate varied between $11.6-162 \mathrm{~mL} / \mathrm{h}$. The results (Figure 6) showed that maximal protein content $(0.64 \mathrm{mg} / \mathrm{mL})$ with highest MCA $(2.56 \mathrm{U} / \mathrm{mL})$ occurred at low dilution rate $(0.05 / \mathrm{h})$ and gradually decreased as the dilution rate (decrease of residence time) increased. Similarly, Sirisansaneeyakul et al. (2007) suggested that increasing the dilution rate reduces the concentration of the product in the effluent. This trend was expected since the contact time between the medium and the immobilized cells was decreased as the dilution rate increased. The kinetic parameters of the bioreactor with different dilution rates (Table 1) indicated that the bioreactor productivity (dilution rate $\mathrm{x}$ enzyme activity) increased with the increase in the dilution rate up to $0.5 / \mathrm{h}$ (residence time of $2 \mathrm{~h}$ ), whereby maximal bioreactor productivity was attained of $0.385 \mathrm{KU} / \mathrm{L} / \mathrm{h}$. The performance of the operational stability of the

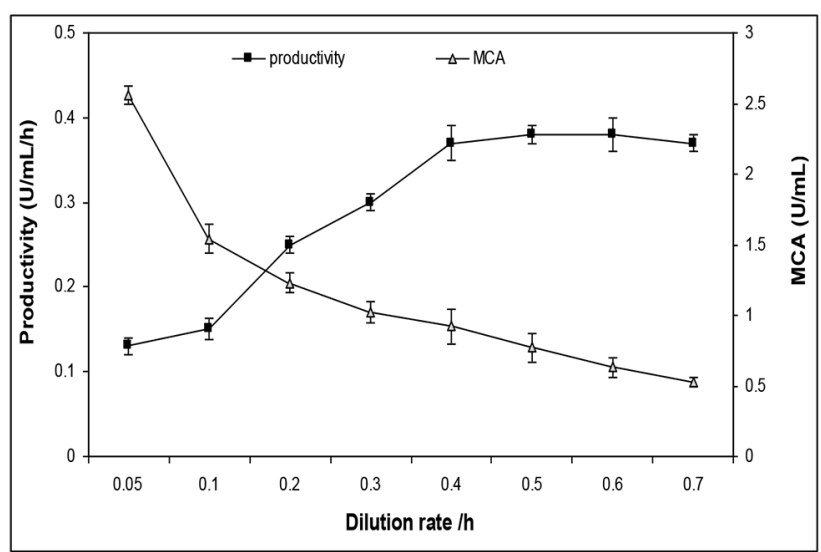

Figure 6. Effect of dilution rate on continuous production of MCE by immobilized cells.

bioreactor at different dilution rates indicted that, at the optimum dilution rate $(0.5 / \mathrm{h})$, the bioreactor was able to keep producing MCA of about $0.7 \mathrm{U} / \mathrm{mL}$ with MCA/PA activity ratio of 11.0 for about 7 days at the same level. Then, the activity started to decline gradually to the level of $0.28 \mathrm{U} / \mathrm{mL}$ after 20 days of operation (data not shown). The long term viability and continuous metabolic activity is one of the most important advantages when working with continuous fermentation using immobilized biocatalyst

\section{Comparison of MCA and productivity in various systems}

Comparison of MCA and productivity of the free and immobilized cells of $B$. circulans 25 in various systems is presented in Table 2. The highest MCA was achieved by free cells $(1.33 \mathrm{U} / \mathrm{mL})$ in batch fermentation which is $33 \%, 66 \%$, and $73 \%$ higher than the immobilized cells in batch, repeated batch and continuous systems, respectively. On the other hand, the productivity of the immobilized cells under continuous operation in the bioreactor resulted in $0.385 \mathrm{KU} / \mathrm{L} / \mathrm{h}$, which is higher than the free cells, immobilized cells in batch and

Table 1. Kinetic parameters for the production of MCA by immobilized B. circulans 25 cells on wool in continuous culture.

\begin{tabular}{|c|c|c|c|c|c|c|}
\hline Dilution rate $(/ \mathrm{h})(\mathrm{A})$ & Residence time (h) & $\begin{array}{l}\text { Protein content } \\
\quad(\mathrm{mg} / \mathrm{mL})\end{array}$ & $\operatorname{MCA}(\mathrm{U} / \mathrm{mL})(\mathrm{B})$ & $\begin{array}{c}\text { Total units of MCA } \\
(\mathrm{U} / \mathrm{h})\end{array}$ & $\begin{array}{c}\text { productivity (U/ } \\
\text { mL/h) (A x B) }\end{array}$ & $\begin{array}{c}\text { Specific } \\
\text { productivities } \\
(\mathrm{U} / \mathrm{g} \text { wet cells } / \mathrm{h} \text { ) }\end{array}$ \\
\hline 0.05 & 20.00 & 0.64 & 2.56 & 11.90 & 0.13 & 2.27 \\
\hline 0.1 & 10.00 & 0.63 & 1.54 & 14.30 & 0.15 & 2.72 \\
\hline 0.2 & 5.00 & 0.58 & 1.23 & 22.90 & 0.25 & 4.36 \\
\hline 0.3 & 3.33 & 0.57 & 1.00 & 27.90 & 0.30 & 5.31 \\
\hline 0.4 & 2.50 & 0.57 & 0.92 & 34.34 & 0.37 & 6.54 \\
\hline 0.5 & 2.00 & 0.56 & 0.77 & 35.76 & 0.38 & 6.81 \\
\hline 0.6 & 1.66 & 0.54 & 0.63 & 35.15 & 0.38 & 6.69 \\
\hline 0.7 & 1.43 & 0.52 & 0.53 & 34.76 & 0.37 & 6.62 \\
\hline
\end{tabular}


Table 2. Comparison of MCA and productivity in various systems.

\begin{tabular}{|c|c|c|c|c|c|c|}
\hline Production systems & $\operatorname{MCA}(\mathrm{U} / \mathrm{mL})$ & $\begin{array}{c}\mathrm{MCA} / \mathrm{PA} \\
\text { ratio }\end{array}$ & $\begin{array}{l}\text { Rate of enzyme } \\
\text { production }(\mathrm{U} / \mathrm{h})\end{array}$ & $\begin{array}{c}\text { Specific } \\
\text { productivity }(\mathrm{U} / \mathrm{g} \\
\text { wet cells } / \mathrm{h})\end{array}$ & $\begin{array}{l}\text { Productivity } \\
\text { (KU/L/h) }\end{array}$ & $\begin{array}{c}\text { Relative } \\
\text { productivity } \\
\text { (- fold) }\end{array}$ \\
\hline Free cells Batch & 1.33 & 15.10 & 2.77 & 13.88 & 0.055 & 1.00 \\
\hline \multicolumn{7}{|l|}{ Immobilized cells } \\
\hline 1. Batch & 1.00 & 11.11 & 2.08 & 10.40 & 0.042 & 0.76 \\
\hline 2. Repeated batch (Average of 8 cycles) & 0.80 & 11.08 & 1.66 & 8.33 & 0.033 & 0.61 \\
\hline 3. Continuous (dilution rate $0.5 / \mathrm{h}$ ) & 0.77 & 17.70 & 89.32 & 17.01 & 0.385 & 7.00 \\
\hline
\end{tabular}

in repeated batch operations by 7, 9.2 and 11.7-fold, respectively. Gungormusler et al. (2011) reported that the production in a packed-bed bioreactor designed with an immobilization system achieved 2.5-fold higher productivity compared to the free system.

\section{CONCLUSIONS}

Cell immobilization is a technique that restricts the free movement of microorganisms in the process, and it has many advantages. Natural wool is an attractive and suitable as an immobilization carrier because it is cheap, available and non-toxic. Immobilization of $B$. circulans 25 cells on natural wool by covalent binding is promising for milk-clotting enzyme production by batch, repeated batch and continuous fermentation. In repeated batch, immobilized cells on natural wool were able to produce the same level of MCA, productivity and MCA/PA for 9 cycles (216 h). Under continuous operation, immobilized cells in a packed-bed bioreactor were able to keep producing MCA with MCA/PA ratio for about 7 days at the same level. Moreover, continuous operation produces productivity of $0.385 \mathrm{KU} / \mathrm{L} / \mathrm{h}$ which is higher than the other systems by $7.0-11.7$ fold. The long term viability and continuous metabolic activity is one of the most important advantages when working with continuous fermentation using an immobilized biocatalyst.

\section{REFERENCES}

Abd El-Ghaffar, M. A. and Hashem, M. S., Chitosan and its amino acids condensation adducts as reactive natural polymer supports for cellulase immobilization. Carbohydrate Polymers, 81, 507516 (2010).

Abdel-Naby, M.A., Osman, M.Y. and AbdelFattah, A.F., Production of pullulanase by free and immobilized cells of Bacillus licheniformis NRC22 in batch and continous cultures. World Journal of Microbiology Biotechnology, 27, 29032911(2011).
Ahmed, S. A. and Abdel-Fattah, A.F., Production of Bacillus licheniformis ATCC 21415 alkaline protease in batch, repeated batch and continuous culture. Malaysian Journal of Microbiology, 6, 156-160 (2010).

Ahmed, S.A., Wehaidy, Hala. R.Ibrahim, O.A., Abd ElGhani, S. and El-Hofi, M.A., Novel milk-clotting enzyme from Bacillus stearothermophilus as a coagulant in UF-white soft cheese. Biocatalysis and Agricultural Biotechnology, 7, 241-249 (2016).

An, J.D., Patterson, D.A., McNeil, S. and Hossain, M.M., Immobilization of lipase on woolen fabrics: Enhanced effectiveness in stain removal. Biotechnology Progress, 30, 806-817 (2014).

Bagherinejad, M.R., Korbekandi, H., Tavakoli, N. and Abedi, D., Immobilization of penicillin G acylase using permeabilized Escherichia coli whole cells within chitosan beads. Research Pharmaceutical Sciences, 7, 79-85 (2012).

Berridge, N.J., Some observation on the determination of the activity of rennet. Analyst (lond.), 77, 57-62 (1952).

Chang, M.-Y., Kao, C-H. andJuang, R.-S., Thermal inactivation and reactivation of $\beta$-glucosidase immobilized on chitosan-clay composite. International Journal ofBiological Macromolecules, 43, 48-53 (2008).

Cheetham, P.S.J., Garrett, C. and Clark, J., Isomaltulose production using immobilized cells. Biotechnology and Bioengineering, 27, 471-481 (1985).

Chibata, I., Tosa, T. and Sato, T., Immobilization of enzymes and cells. Methods Enzymology, 44, 739745 (1976).

Costa, H., Gastón, J.R., Lara, J., Martinez, C.O., Moriwaki, C., Matioli, G. and Ferrarotti, S.A., Cyclodextrin glycosyltransferase production by free cells of Bacillus circulans DF 9R in batch fermentation and by immobilized cells in a semicontinuous process. Bioprocess and Biosystems Engineering, 38, 1055-1063 (2015).

Deane, S.M., Robb, F.T. and Wood, D.R., Isolation and characterization of a Vibrio alginolyticus mutant 
that over produced extracellular proteases. Journal of General Microbiology, 132, 893-898 (1986).

Eş, I.,Vieira, J.D.G. and Amaral, A.C., Principles, techniques, and applications of biocatalyst immobilization for industrial application. Applied Microbiology Biotechnology, 99, 2065-2082 (2015).

Gungormusler, M., Gonen, C. and Azbar, N., Continuous production of 1, 3-propanediol using raw glycerol with immobilized Clostridium beijerinckii NRRL B- 593 in comparison to suspended culture. Bioprocess and Biosystems Engineering, 34, 727-733 (2011).

Hang, F., Liu, P., Wang, Q., Han, J., Wu, Z., Gao, C., Liu, Z., Zhang, H. and Chen, W., High milkclotting activity expressed by the newly isolated Paenibacillus spp. strain BD3526. Molecules, 21, 73, 1-14 (2016).

Konti,A., Mamma, D.I,Hatzinikolaou,D.G. andKekos, D., 3-Chloro-1,2-propanediol biodegradation by Ca-alginate immobilized Pseudomonas putida DSM 437 cells applying different processes: mass transfer effects. Bioprocess and Biosystems Engineering, 39,1597-1609 (2016).

Krasňan, V.,Stloukal, R., Rosenberg, M. and Rebroš, M., Immobilization of cells and enzymes to LentiKats(r). Applied Microbiology Biotechnology, 100, 2535-2553 (2016).

Lemes, A.C., PavÓn, Y., Lazzaroni, S., Rozycki, S., Brandelli, A. and Kalil, S. J., A new milk-clotting enzyme produced by Bacillus sp. P45 applied in cream cheese development. LWT - Food Science and Technology, 66, 217-224 (2016).

Lowry, O.H., Rosebrough, N.J., Farr, A.L. and Ranall, R.T., Protein measurement with the folin phenol reagent. Journal of Biological Chemistry,193, 265276 (1951).

Niknezhad, S.V., Asadollahi, M.A., Zamani, A. and Biria, D., Production of xanthan gum by free and immobilized cells of Xanthomonas campestris and
Xanthomonas pelargonii. International Journal of Biological Macromolecules, 82, 751-756 (2016).

Panesar, R., Panesar, P.S., Singh, R.S. and Bera, M.B., Applicability of alginate entrapped yeast cells for the production of lactose-hydrolyzed milk. Journal of Food Process Engineering, 30, 472-484 (2007).

Reddy, L.V., Kim, Y.M., Yun, J.S., Ryu, H.W. and Wee, Y.J., L-Lactic acid production by combined utilization of agricultural bioresources as renewable and economical substrates through batch and repeated-batch fermentation of Enterococcus faecalis RKY1. Bioresource Technology, 209, 187194 (2016).

Saieb, F.M., Boaker, S.A., El-komy, H.M. andIssa, A., Production and estimation of keratinase by immobilized and free Bacillus licheniformis (St.24). Journal of Applied and Environmental Microbiology, 3, 119-122 (2015).

Shah, M.A., Mir, S.A. and Paray, M.A., Plant proteases as milk-clotting enzymes in cheese making: a review. Dairy Science and Technology, 94, 5-16 (2014).

Shamtsyan, M., Dmitriyeva, T., Kolesnikov, B. and Denisova, N., Novel milk clotting enzyme produced by Coprinus lagopides basidial mushroom. LWTFood Science and Technology, 58, 343-347 (2014).

Siddiqui, M., Siddiqui, N. and Varma, R., Enhanced production of cellulolytic enzymes from immobilized cells of Aspergillus niger. International Journal of Pure and Applied Bioscience, 4, 109-114 (2016).

Sirisansaneeyakul, S., Luangpipat, T., Vanichsriratana, W., Srinophakun, T., Chen, H.H. and Chisti, Y., Optimization of lactic acid production by immobilized Lactococcus lactis IO-1. Journal of Industrial Microbiology and Biotechnology, 34, 381-391 (2007).

Wu, F.C., Chang, C.W. and Shih, I.L., Optimization of the production and characterization of milk clotting enzymes by Bacillus subtilis natto. Springer Plus, 2, 33, 1-10 (2013). 
